ISSN 0103-9954

\title{
EFEITO DO ÁCIDO INDOL-3-BUTÍRICO (AIB) NO ENRAIZAMENTO DE MINIESTACAS DE IPÊ-ROXO (Handroanthus heptaphyllus MATTOS)
}

\author{
EFFECT OF INDOL-3- BUTIRIC ACID (AIB) ON THE ROOTING OF 'IPÊ-ROXO” \\ (Handroanthus heptaphyllus MATTOS ) MINICUTTINGS
}

\author{
Taiane Pires de Freitas de Oliveira ${ }^{1}$ Deborah Guerra Barroso ${ }^{2}$ Kelly Ribeiro Lamônica ${ }^{3}$ \\ Virgínia Silva Carvalho ${ }^{2}$ Marcos André de Oliveira ${ }^{4}$
}

\begin{abstract}
RESUMO
A Handroanthus heptaphyllus Mattos, conhecida popularmente como ipê-roxo, é propagada comumente por via seminal, no entanto, suas sementes quando armazenadas, perdem rapidamente o poder germinativo, sendo assim, uma alternativa de propagação para esta espécie é a propagação vegetativa, técnica que favorece a produção de mudas em escala comercial, além de possibilitar ganho de características esperadas como uniformidade da muda no viveiro. O objetivo deste trabalho foi avaliar o efeito de diferentes concentrações de ácido indol-3-butírico (AIB) no enraizamento de miniestacas apicais de ipê-roxo. As miniestacas foram provenientes da primeira coleta de brotações das minicepas do minijardim multiclonal conduzido em tubetes realizada aos 231 dias após a germinação. Após a coleta, as miniestacas foram submetidas a cinco concentrações de AIB $\left(0 ; 2000 ; 4000,6000\right.$ e $\left.8000 \mathrm{mg} \mathrm{L}^{-1}\right)$ e em seguida foram estaqueadas em tubetes contendo Basaplant Florestal ${ }^{\circledR}$ e adubo de liberação lenta (Osmocote ${ }^{\circledR}$ 14-14-14). O experimento foi conduzido em delineamento inteiramente casualizado, com quatro repetições, compostas por dez miniestacas. Aos 30 dias, as miniestacas foram avaliadas quanto à sobrevivência, número de raízes de primeira e segunda ordem, comprimento das raízes de primeira ordem e massa seca do sistema radicular. Ao final do ciclo de produção, aos quatro meses, as mudas foram avaliadas quanto à altura, diâmetro do coleto, número de folhas, área foliar, massa seca da parte aérea, número e comprimento das raízes primárias e massa seca do sistema radicular. Observou-se mais de 95\% de sobrevivência das miniestacas, aos 30 dias, em todos os tratamentos, com $80 \%$ delas enraizadas na ausência do fitorregulador. No entanto, o número de raiz de segunda ordem foi maior nas mudas submetidas a $8000 \mathrm{mg} \mathrm{L}^{-1}$. A utilização de AIB em miniestacas de ipê-roxo não é um condicionante para o enraizamento, embora tenha resultado em mudas com maior comprimento de raízes de primeira ordem e número de raízes de segunda ordem na concentração de 8000 $\operatorname{mg~L}{ }^{-1}$.
\end{abstract}

Palavras-chave: propagação vegetativa; miniestaquia; enraizamento adventício.

1 Engenheira Florestal, MSc., Doutoranda do Programa de Pós-Graduação em Produção Vegetal, Universidade Estadual do Norte Fluminense Darcy Ribeiro, Centro de Ciências e Tecnologias Agropecuárias, Laboratório de Fitotecnia, Av. Alberto Lamego, 2000, Parque Califórnia, CEP 28013-602, Campos dos Goytacazes (RJ), Brasil. ibitaiane@hotmail.com

2 Engenheira Agrônoma, Dra ${ }^{\mathrm{a}}$, Professora da Universidade Estadual do Norte Fluminense Darcy Ribeiro, Centro de Ciências e Tecnologias Agropecuárias, Laboratório de Fitotecnia, Av. Alberto Lamego, 2000, Parque Califórnia, CEP 28013-602, Campos dos Goytacazes (RJ), Brasil. deborah@uenf.br/ virginiascar@gmail.com

3 Engenheira Agrônoma, Dra ${ }^{\mathrm{a}}$., Professora do Instituto Fluminense Federal, Av. Dário Vieira Borges, 235, Parque do Trevo, CEP 28360-000, Bom Jesus do Itabapoana (RJ), Brasil. krlamonica@gmail.com

4 Graduando em Engenharia Agronômica, Universidade Estadual do Norte Fluminense Darcy Ribeiro, Centro de Ciências e Tecnologias Agropecuárias, Laboratório de Fitotecnia, Av. Alberto Lamego, 2000, Parque Califórnia, CEP 28013-602, Campos dos Goytacazes (RJ), Brasil. marcosagronoliveira@bol.com.br

Recebido para publicação em 12/06/2012 e aceito em 17/04/2014

Ci. Fl., v. 25, n. 4, out.-dez., 2015 


\begin{abstract}
The Handroanthus heptaphyllus Mattos know as "ipê-roxo" is usually propagated by seeds. An propagation alternative for species. Is the vegetative propagation, technique that stimulates seedling production on a commercial scale besides the expected gain in characteristic as the uniformity of seedlings in the nursery. The objective of this work was the evaluation the effect of different concentrations of indol-3-butiric acid (AIB) on the apical minicutting rooting of this species. The cuttings were collected from the first ministumps shoots of the minigarden conducted in tubes, 231 days after germination. After the collect the minicuttings were submitted to five AIB concentrations $\left(0 ; 2,000 ; 4,000 ; 6,000\right.$ and $\left.8,000 \mathrm{mg} \mathrm{L}^{-1}\right)$. Then were planted in tubes with Basaplant Forest ${ }^{\circledR}$ substrate and slow release fertilizer (Osmocote ${ }^{\circledR}$ 14-14-14). The experiment was carried out in a completely randonmized design with four replicates constituted by ten minicuttings. At 30 days the minicuttings were evaluated about survival, number of roots of the first and second orders, length of first order root and dry mass of the root system. At four months the cuttings were evaluated in height, root-collar diameter, number of leaves, leaf area, stem dry weight, number and length of first order roots and root dry weight. More than 95\% survival the minicuttings was observed at 30 days in all treatments, and $80 \%$ of them rooted without IBA. However, the number of the second order roots was higher in cuttings submitted to $8,000 \mathrm{mg} \mathrm{L}^{-1}$. The use of IBA is not a condition for rooting of $H$. heptaphyllus cuttings, although it results in seedlings with longer roots of the first order and number of roots of the second order in the concentration of $8000 \mathrm{mg} \mathrm{L}^{-1}$.
\end{abstract}

Keywords: vegetative propagation; minicutting; rooting.

\section{INTRODUÇÃO}

A Handroanthus heptaphyllus Mattos, sinonímia Tabebuia heptaphylla (Velloso) Toledo, conhecida vulgarmente como ipê-roxo, ipê-ipiranga e ipê-preto, é uma espécie da família Bignoniaceae (LORENZI, 2002). Árborea, caducifólia, com 8 a $20 \mathrm{~m}$ de altura, esta essência florestal pode atingir 35 $\mathrm{m}$ de altura e $150 \mathrm{~cm}$ de DAP. Pode ser encontrada com frequência em áreas de vegetação nativa nos estados do Espírito Santo, Bahia, Minas Gerais, Rio de Janeiro, São Paulo, Rio Grande do Sul e Mato Grosso do Sul, além de outros países da América do Sul, como por exemplo, Argentina, sul da Bolívia, leste do Paraguai e Uruguai, em ambientes com precipitações pluviométricas variando de $1000 \mathrm{~mm}$ a $1900 \mathrm{~mm}$ anualmente e temperaturas de 18 a $26^{\circ} \mathrm{C}$ (CARVALHO, 1994).

Esta espécie tem sido utilizada para reconstituição de Reserva Legal (BRASIL, 2002) e programas de recuperação de áreas degradadas, além de ser empregada na medicina popular para o tratamento contra alguns tipos de câncer, lúpus, doença de Parkinson, psoríase e alergia, além de apresentar atividades hipoglicemiante, depurativo, bactericida, antifúngico, diurético e adstringente (NETO e MORAIS, 2003; POTT e POTT, 1994).

Sua madeira é muito procurada e de alto valor econômico e possui elevada densidade e durabilidade, resistente e de baixa retratilidade volumétrica, sendo empregada na construção civil, como quilhas de navios, mourões, pontes e assoalhos, confecções de bengalas, além de produzir carvão de boa qualidade (PAULA e ALVES, 2007).

$\mathrm{O}$ ipê-roxo é comumente propagado via seminífera, no entanto, as sementes quando armazenadas apresentam variações em termos de qualidade, reduzindo o poder germinativo ao longo do tempo (CARVALHO, 1994). Segundo Maeda e Matthes (1984), em condições ambientais de armazenamento, suas sementes apresentam-se com $50 \%$ de germinação aos 160 dias após a colheita. Sendo assim, uma alternativa de propagação para as espécies que apresentam dificuldade no armazenamento de sementes, no potencial germinativo ou produção insuficiente de sementes é a propagação vegetativa por miniestaquia (SANTOS, 2002), técnica que favorece a produção de mudas em escala comercial, além de possibilitar ganho de características esperadas como uniformidade das mudas no viveiro. No Brasil, esta tem sido a técnica mais empregada pelas empresas florestais para a propagação de espécies do gênero Eucalyptus.

O enraizamento adventício é uma etapa essencial na propagação vegetativa, constituindo um fator limitante de utilização da técnica, pois pode ser afetado pelo genótipo, idade e nutrição da planta fornecedora de propágulos, condições ambientais 
(luminosidade, temperatura, umidade), estações do ano de coleta das estacas (HARTMANN et al., 2002), além dos tratos culturais, como a irrigação e controle de doenças e pragas. Outro fator importante a ser considerado são as substâncias promotoras do enraizamento adventício que pertencem ao grupo das auxinas naturais e sintéticas (GATTI, 2002). A principal auxina natural das plantas é o ácido indolacético (AIA), encontrado em níveis que variam conforme a velocidade das reações de síntese, destruição e inativação e que, por sua vez, é afetada por fatores como idade fisiológica do órgão e da planta, condições ambientais, e parte da planta que foi analisada (FACHINELLO et al., 1995). Sua biossíntese está associada com locais de divisão celular rápida, especialmente, nas gemas apicais, folhas jovens, frutos em desenvolvimento e em sementes, e a partir daí é translocada basipetamente até o coleto da planta e acropetamente até o ápice das raízes (TAIZ e ZEIGER, 2004).

Dentre as várias auxinas sintéticas, as mais utilizadas para o enraizamento de propágulos vegetativos são o ácido indolbutírico (AIB) (BRONDANI et al., 2008) e o ácido naftalenacético (ANA), e quando são aplicadas exogenamente em estacas, estimulam a formação de raízes adventícias, aumentando a porcentagem de estacas enraizadas, o número de raízes formadas e a uniformidade do enraizamento (HARTMANN et al., 2002; TAIZ e ZEIGER, 2004). No entanto, os resultados encontrados em experimentos avaliando doses de auxinas apresentam variações conforme a espécie, época do ano, concentração e condições ambientais (FACHINELLO et al., 1995). Além dessas auxinas, o 2,4-diclorofenoxiacético (2,4-D) e o ácido naftoxiacético (NOA) também podem ser utilizadas como promotoras de enraizamento.

Em miniestacas de clones de Eucalyptus benthmii x Eucalyptus dunnii, Brondani et al. (2008) avaliaram diferentes concentrações de AIB $\left(0,1000,3000,6000\right.$ e $\left.8000 \mathrm{mg} \mathrm{L}^{-1}\right)$, veiculado em gel, e verificaram que a dose de máxima eficiência técnica ocorreu na concentração de 4421,9 mg $\mathrm{L}^{-1}$, correspondendo a um enraizamento de $43,2 \%$, independente do clone. A necessidade de aplicação de ácido indolbutírico (AIB) no enraizamento de miniestacas também tem sido estudada em diversas outras espécies, dentre elas o Eucalyptus grandis (TITON et al., 2001), Eucalyptus cloeziana (ALMEIDA et al., 2007), Toona ciliata (Souza et al., 2009), Sapium glandulatum (FERREIRA et al., 2010), Eugenia uniflora L. (LATTUADA,
2010) e Anadenanthera macrocarpa (DIAS et al., 2012) entre as quais, as duas primeiras mostraramse dependentes da auxina para promover maiores índices de enraizamento, enquanto as demais, não necessitam do hormônio.

Para a viabilidade da técnica de miniestaquia é importante a avaliação do potencial de enraizamento das miniestacas e da necessidade de aplicação de auxinas exógenas. Não há na literatura trabalhos que indiquem o potencial de enraizamento de miniestacas de $H$. heptaphyllus, tampouco informações sobre a necessidade de utilização de auxina exógena no enraizamento. Sendo assim, o trabalho teve como objetivo avaliar o efeito da aplicação de diferentes concentrações de ácido indol-3-butírico (AIB) no enraizamento de miniestacas apicais de ipê-roxo (Handroanthus heptaphyllus Mattos).

\section{MATERIAL E MÉTODOS}

O experimento foi conduzido entre os meses de maio a setembro de 2011 em casa de vegetação coberta com plástico de polipropileno (150 $\mu \mathrm{m})$ e sombrite $(30 \%)$ localizada na Universidade Estadual do Norte Fluminense Darcy Ribeiro, no município de Campos dos Goytacazes - RJ, com latitude $21^{\circ} 19^{\prime} 23^{\prime \prime}$ 'S e longitude $41^{\circ} 19^{\prime} 41^{\prime \prime} \mathrm{W}$. De acordo com a classificação de Köppen, o clima da região é do tipo $\mathrm{Aw}$, tropical quente e úmido, com período de estiagem no inverno e chuvoso no verão. Durante os meses de condução do experimento registraram-se médias de temperatura e umidade relativa de $21,6^{\circ} \mathrm{C}$ e $76,5 \%$, respectivamente.

As miniestacas utilizadas foram provenientes da primeira coleta de brotações realizada aos três meses após a poda apical, em minijardim multiclonal de Handroanthus heptaphyllus, formado a partir de sementes e cultivados em tubetes de polipropileno com capacidade de $280 \mathrm{~cm}^{3}$ contendo Basaplant Florestal ${ }^{\circledR}$ como substrato e adubo de liberação lenta (Osmocote $\left.{ }^{\circledR} 14-14-14\right)$, na concentração de $8 \mathrm{~g} \mathrm{~kg}^{-1}$ de substrato. Após serem coletadas, as miniestacas apicais foram preparadas com um corte reto na base e com aproximadamente $5 \mathrm{~cm}$ de comprimento, mantida uma folha em cada lado, com redução de $50 \%$ de sua área foliar. Antes de serem colocadas no substrato, as miniestacas tiveram a base mergulhada por 2 segundos no regulador de crescimento AIB por via líquida, com diferentes concentrações: 0 ; 2000; 4000, 6000 e $8000 \mathrm{mg} \mathrm{L}^{-1}$. As soluções de 
AIB foram preparadas com $50 \%$ de álcool etílico P.A. para diluir a auxina.

Posteriormente, as miniestacas foram dispostas em delineamento inteiramente casualizado - DIC, com quatro repetições, compostas por dez miniestacas por parcela em câmara de nebulização com cobertura plástica de polipropileno de $150 \mu \mathrm{m}$, sob nebulização intermitente, com pulverizações de 15 segundos, a cada 15 minutos, mantendo assim, o controle da umidade.

As miniestacas foram monitoradas até a formação das raízes, que foram detectadas pela resistência ao leve toque de remoção da miniestaca do substrato e ainda a visualização dos primórdios radiculares após remoção da superfície do substrato (aproximadamente $5 \mathrm{~mm}$ ), conforme Freitas et al. (2009). Sendo assim, aos 30 dias, ao serem expedidas da câmara de nebulização, as mudas foram avaliadas quanto à sobrevivência. Foram consideradas mortas, aquelas que se apresentavam sem folhas, com coloração escura e desidratadas, sendo então descartadas.

Para avaliação do número de raízes de primeira e segunda ordem, comprimento das raízes de primeira ordem e massa seca do sistema radicular, foram retiradas quatro plantas por parcela aos 30 dias após o estaqueamento, na expedição do setor de enraizamento.

Para essas avaliações, as mudas foram cortadas à altura do colo, e o sistema radicular foi lavado, retirando-se todo o excesso de substrato para contagem e medição das raízes. Posteriormente, o material foi colocado em sacos de papel, e levados para estufa de circulação forçada a $65^{\circ} \mathrm{C} \pm 2$, por 72 horas, para pesagem.

O restante das mudas de cada parcela foi mantido no setor de aclimatização e crescimento em casa de vegetação, e ao final de quatro meses, as mudas foram avaliadas quanto à altura e diâmetro. E para avaliação do número de folhas, área foliar, massa seca da parte aérea, número e comprimento das raízes primárias e massa seca do sistema radicular, foram utilizadas quatro mudas por parcela.

Para medição da altura e diâmetro, foram utilizados respectivamente, uma régua e um paquímetro digital. A área foliar foi determinada pelo medidor de área foliar eletrônico de bancada (LI-3000, LI-COR Inc.). Para avaliar o sistema radicular, foi retirado todo o excesso de substrato com água, usando peneiras para reter as raízes. $\mathrm{O}$ comprimento das raízes foi medido com auxílio de uma régua e para avaliar a massa seca, tanto a parte aérea quanto o sistema radicular das mudas, foram colocados separadamente em sacos de papel, devidamente identificados, em estufa de circulação forçada a $65^{\circ} \mathrm{C} \pm 2$ por 72 horas, para posterior pesagem em balança analítica.

Durante a permanência das mudas na casa de vegetação, a irrigação foi mantida constante, sendo irrigadas duas vezes por dia, nos períodos mais frescos do dia (início da manhã e final da tarde), com alterações, conforme a necessidade.

Os dados foram submetidos aos testes de Cochran e Lilliefors, sendo realizada transformação quando os mesmos não apresentaram homocedasticidade e distribuição normal. Para os dados de contagens, os resultados obtidos foram transformados em $\log (\mathrm{x}+1)$ e os dados de percentagem para $(\mathrm{X}+1)^{1 / 2}$, antes de realizar as análises de variância (ZIMMERMANN, 2004). Após a transformação, os dados foram submetidos à análise de variância e as médias comparadas pelo teste de Tukey em 5\% de probabilidade. Para a análise em função de variáveis fixas quantitativas, os dados foram submetidos a ajustes de regressão.

\section{RESULTADOS E DISCUSSÃO}

Durante a fase de enraizamento, houve aproximadamente $95 \%$ de sobrevivência das miniestacas em todos os tratamentos. Esse resultado assemelha-se ao encontrado por Souza et al. (2009) com Toona ciliata (100\%), e por Brandoni et al. (2008) em dois clones de Eucalyptus benthamii x Eucalyptus dunnii (H23 e H27), respectivamente, $95,7 \%$ e $92,9 \%$. Gatti (2002) obteve uma média de 90,1\% de sobrevivência em miniestacas de Tectona grandis, atribuindo a mortalidade ocorrida ao excesso de irrigação no ambiente de enraizamento. Já Sampaio et al. (2010) encontraram 81,6\% de sobrevivência em miniestacas de Aniba canellila. Esta é a fase da propagação vegetativa em que são registradas as maiores taxas de mortalidade de miniestacas, podendo atingir mais de 20\% (ZANNI FILHO, 1997). Neste caso, os resultados encontrados por esses autores estão dentro do intervalo esperado para que a produção de mudas por miniestaquia seja considerada técnica e economicamente viável.

Observa-se na Figura 1 que apenas as raízes de segunda ordem tiveram o número influenciado pelos tratamentos, com comportamento cúbico em função das doses de AIB. Houve aumento no número das raízes com a dose de $2000 \mathrm{mg} \mathrm{L}^{-1}$, queda posterior e acentuado aumento no número 


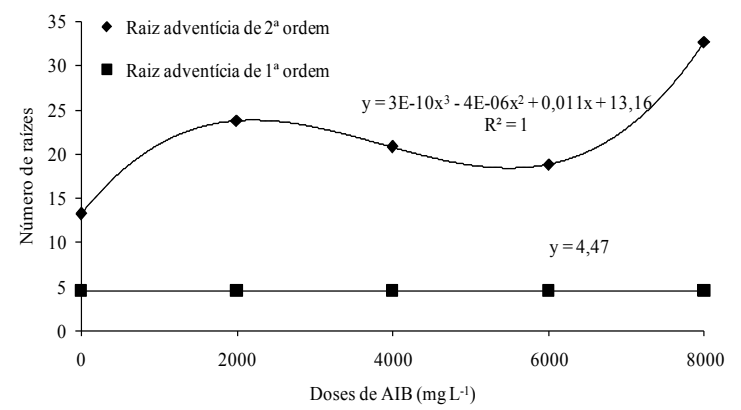

FIGURA 1: Número de raízes adventícias de primeira e segunda ordem em miniestacas de Handroanthus heptaphyllus, aos 30 dias após o estaqueamento, provenientes da coleta realizada aos três meses após a poda apical das minicepas, em função das doses de ácido indol-3-butírico. Ano 2011.

FIGURE 1: Number of adventitious roots of first and second order in the Handroanthus heptaphyllus cuttings at 30 days after striking, from the collection held at three months after the pruning of ministumps, depending on the doses of indole-3-butyric. Year 2011.

de raízes na dose de $8000 \mathrm{mg} \mathrm{L}^{-1}$. O número das raízes de primeira ordem não variou em função dos tratamentos.

Essas raízes de segunda ordem são mais finas que as de primeira ordem, e são justamente as responsáveis por grande parte da absorção de água e nutrientes (ANDERSEN e BENTSEN, 2003).

De acordo com Hartmann et al. (2002), o aumento da concentração de auxinas aplicadas em estacas, estimula a indução de raízes até um ponto máximo, a partir do qual qualquer acréscimo do nível de auxina se torna inibitório. Entretanto, no presente estudo, as miniestacas de ipê-roxo responderam positivamente à maior dose testada, possibilitando fazer inferências que, para essa espécie, seria necessária uma concentração mais alta de AIB para inibir a indução de raízes.

Houve comportamento quadrático no percentual de miniestacas enraizadas, entretanto, a redução apresentada na maior dose utilizada foi praticamente inexpressiva para enraizamento de estacas de espécies lenhosas (Figura 2). A concentração de AIB que promoveu maior

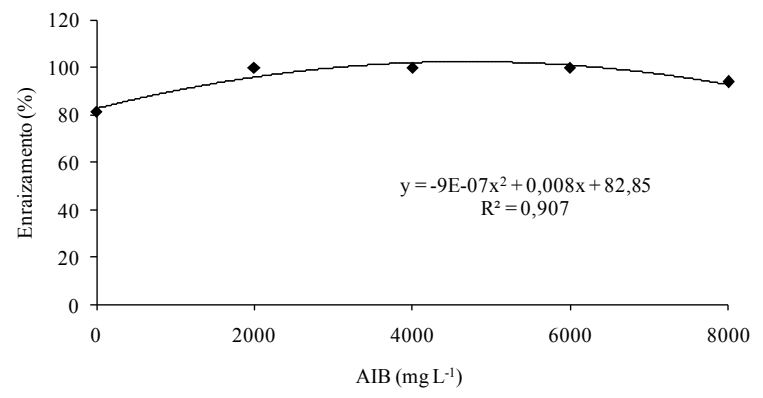

FIGURA 2: Enraizamento em miniestacas de Handroanthus heptaphyllus, aos 30 dias após o estaqueamento, provenientes da coleta realizada aos três meses após a poda apical das minicepas, em função das doses de ácido indol-3-butírico. CV(\%) 8,32.

FIGURE 2: Rooting in cuttings of Handroanthus heptaphyllus, 30 days after striking, from the collection held at three months after the pruning of ministumps, depending on the doses of indole-3butyric acid. CV (\%) 8,32.

percentual de enraizamento das miniestacas foi de $4444 \mathrm{mg} \mathrm{L}^{-1}$, estimada pelo ponto de máxima eficiência técnica. Apesar de $80 \%$ das miniestacas de ipê-roxo emitir raízes sem a utilização do hormônio de enraizamento (Figura 2), estas, quando tratadas com o AIB, apresentaram maior número de raízes de segunda ordem (Figura 1) que são as responsáveis por grande parte da absorção de água e nutrientes.

Sendo assim, a utilização de fitorregulador deve ser considerada para produção de mudas de ipê-roxo por miniestaquia, conforme o sítio a que se destinam, pois esta espécie, por ser muito utilizada em programas de recuperação de áreas degradadas, necessitaria de um sistema radicular robusto para resistir às condições de estresse nestes ambientes.

O comprimento e a massa seca das raízes não variaram em função dos tratamentos (Tabela 1). Essas variáveis, juntamente com o número de raízes formadas nas miniestacas, são de extrema relevância na produção de mudas, uma vez que mudas com sistema radicular bem formado terão melhores chances de sobrevivência e melhor desenvolvimento pós-plantio.

Lana et al. (2008), avaliando o efeito de diferentes concentrações de AIB no enraizamento 
TABELA 1: Comprimento de raízes de primeira ordem (CRPO) e massa seca de raízes (MSR) em miniestacas de Handroanthus heptaphyllus, aos 30 dias após o estaqueamento, provenientes da coleta realizada aos três meses após a poda apical das minicepas, em função das doses de hormônio de enraizamento (AIB).

TABLE 1: Root length of the first order (CRPO) and dry root (MSR) in the Handroanthus heptaphyllus cuttings at 30 days after striking, from the collection held at three months after the pruning of ministumps, depending on the doses of hormone rooting (IBA).

\begin{tabular}{ccc}
\hline \multirow{2}{*}{ Doses de AIB $\left(\mathrm{mg} \mathrm{L}^{-1}\right)$} & \multicolumn{2}{c}{ Variáveis analisadas } \\
\cline { 2 - 3 } & CRPO & MSR \\
\hline 0 & $18,4 \mathrm{a}$ & $0,0373 \mathrm{a}$ \\
2000 & $26,4 \mathrm{a}$ & $0,0509 \mathrm{a}$ \\
4000 & $23,5 \mathrm{a}$ & $0,0351 \mathrm{a}$ \\
6000 & $25,3 \mathrm{a}$ & $0,0362 \mathrm{a}$ \\
8000 & $29,9 \mathrm{a}$ & $0,0565 \mathrm{a}$ \\
\hline Médias & 24,7 & 0,2160 \\
CV $(\%)$ & 31,6 & 30,3 \\
\hline
\end{tabular}

Em que: Médias seguidas pela mesma letra na coluna não diferem entre si pelo teste de $\mathrm{F}(5 \%)$.

e crescimento de estacas de Eucalyptus urophylla, verificaram que a massa seca das raízes também não foi influenciada pela aplicação do hormônio e que a dose de $8000 \mathrm{mg} \mathrm{L}^{-1}$ causou toxicidade ao enraizamento das estacas. Em contrapartida, Alcântara et al. (2008) verificaram que o comprimento, número e a massa seca das raízes, variáveis estas que definem a qualidade da raiz formada, apresentaram melhores resultados com a aplicação de $250 \mathrm{mg} \mathrm{L}^{-1}$ de AIB em miniestacas de Pinus taeda.

Todavia, nota-se que os resultados divergem entre si, pois a resposta à aplicação de auxina difere conforme o genótipo, a espécie e o tipo de miniestaca utilizada (HARTMANN et al., 2002).

Ao final dos 4 meses, foi avaliada a qualidade das mudas formadas e, independentemente da dose de AIB utilizada, a sobrevivência não foi alterada em relação à encontrada na fase de enraizamento.

Houve um comportamento cúbico do número de folhas por muda em função das doses de AIB aplicadas. Na dose $2000 \mathrm{mg} \mathrm{L}^{-1}$, houve um pequeno aumento do número de folhas em relação à dose $0 \mathrm{mg} \mathrm{L}^{-1}$, o que, mesmo assim, foi inferior ao valor observado no tratamento com $8000 \mathrm{mg} \mathrm{L}^{-1}$ (Figura 3).

Comparando o número de folhas na Figura 3 e a área foliar na Tabela 2, observa-se que a primeira foi influenciada positivamente pela aplicação do AIB, já a área foliar não apresentou diferença entre as concentrações testadas, indicando que nas mudas que produziram mais folhas, estas, provavelmente,

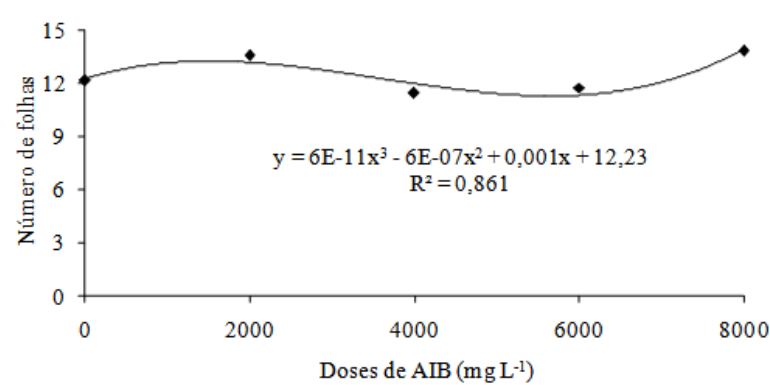

FIGURA 3: Número de folhas de mudas de Handroanthus heptaphyllus produzidas a partir de miniestacas, aos quatro meses após estaqueamento, em função das doses de ácido indol-3butírico. CV (\%): 7,4.

FIGURE 3: Number of leaves Handroanthus heptaphyllus seedlings grown from cuttings, four months after staking, according to the doses of indole-3butyric acid. CV (\%): 7,4.

foram menores, não alterando a área foliar.

Observa-se também na Tabela 2 que não houve efeito do AIB sobre a altura, diâmetro do colo, massa seca da parte aérea (MSPA), número de raiz de primeira ordem (NRPO) e massa seca de raízes (MSR) das mudas aos 4 meses após o estaqueamento. Resultados semelhantes foram encontrados por Titon et al. (2003) em quatro clones de Eucalyptus grandis, cujas dosagens de AIB testadas $\left(0,1000,2000\right.$ e $\left.4000 \mathrm{mg} \mathrm{L}^{-1}\right)$ não 
TABELA 2: Altura $(\mathrm{H})$, diâmetro (DAC), área foliar (AF), massa seca da parte aérea (MSPA), número de raiz de primeira ordem (NRPO) e massa seca de raízes (MSR) em mudas de ipê-roxo produzidas por miniestacas aos quatro meses após estaqueamento, ao final do primeiro ciclo de produção, submetidos a cinco doses crescentes de AIB.

TABLE 2: Height $(\mathrm{H})$, diameter (DAC), leaf area (AF), shoot dry mass (MSPA), root number of first-order (NRPO) and dry root (MSR) in seedlings of ipe-purple produced by cuttings at four months after striking, the first end of the production cycle, underwent five increasing doses of IBA.

\begin{tabular}{ccccccc}
\hline \multirow{2}{*}{ Doses de AIB $\left(\mathrm{mg} \mathrm{L}^{-1}\right)$} & $\mathrm{H}(\mathrm{cm})$ & DAC $(\mathrm{mm})$ & $\mathrm{AF}\left(\mathrm{cm}^{2}\right)$ & MSPA $(\mathrm{g})$ & NRPO & MSR $(\mathrm{g})$ \\
\cline { 2 - 7 } 0 & $8,9 \mathrm{a}$ & $3,76 \mathrm{a}$ & $323,9 \mathrm{a}$ & $2,12 \mathrm{a}$ & $6,9 \mathrm{a}$ & $1,11 \mathrm{a}$ \\
2000 & $8,4 \mathrm{a}$ & $3,85 \mathrm{a}$ & $324,2 \mathrm{a}$ & $2,08 \mathrm{a}$ & $8,5 \mathrm{a}$ & $1,08 \mathrm{a}$ \\
4000 & $8,2 \mathrm{a}$ & $4,11 \mathrm{a}$ & $277,0 \mathrm{a}$ & $1,97 \mathrm{a}$ & $8,3 \mathrm{a}$ & $1,07 \mathrm{a}$ \\
6000 & $7,3 \mathrm{a}$ & $4,07 \mathrm{a}$ & $359,9 \mathrm{a}$ & $2,63 \mathrm{a}$ & $9,3 \mathrm{a}$ & $1,07 \mathrm{a}$ \\
8000 & $10,3 \mathrm{a}$ & $4,44 \mathrm{a}$ & $366,7 \mathrm{a}$ & $2,47 \mathrm{a}$ & $9,3 \mathrm{a}$ & $1,28 \mathrm{a}$ \\
\hline Médias & 8,6 & 4,05 & 330,3 & 2,25 & 8,45 & 1,12 \\
\hline CV(\%) & 16,3 & 14,0 & 20,7 & 22,6 & 18,8 & 19,9 \\
\hline
\end{tabular}

Em que: Médias seguidas pela mesma letra na coluna não diferem entre si pelo teste de $\mathrm{F}(5 \%)$.

influenciaram o crescimento em altura e diâmetro do coleto das mudas aos 50 dias de idade.

Já para o jequitibá (Cariniana estrellensis), Gatti et al. (2011) observaram que o AIB na dose de $1000 \mathrm{mg} \mathrm{L}^{-1}$ resultou em maior crescimento em altura e diâmetro do coleto das mudas aos 90 dias.

De acordo com a Figura 4, observa-se que o comprimento das raízes de primeira ordem das mudas aos quatro meses após o estaqueamento apresentou relação linear positiva com relação às concentrações de AIB testada. Segundo Pacheco (2007), o maior comprimento das raízes em estacas tratadas com AIB, pode estar relacionado com a ativação das expansinas que causa alterações na extensibilidade da parede celular. As expansinas são proteínas que, para serem ativadas, dependem da ação das auxinas sobre as proteínas $\mathrm{H}^{+}$- ATPases da membrana plasmática, sendo essa atividade aumentada em presença de auxinas (TAIZ e ZEIGER, 2004).

Em Melaleuca alternifolia, Oliveira et al. (2012) avaliaram entre outros fatores, a influência do AIB $\left(0,500,1000\right.$ e $\left.2000 \mathrm{mg} \mathrm{L}^{-1}\right)$ no enraizamento das miniestacas, e verificaram que a concentração de $500 \mathrm{mg} \mathrm{L}^{-1}$ foi a que proporcionou maior número de raízes e maior massa fresca, sendo que, para o comprimento, não diferiu da concentração de

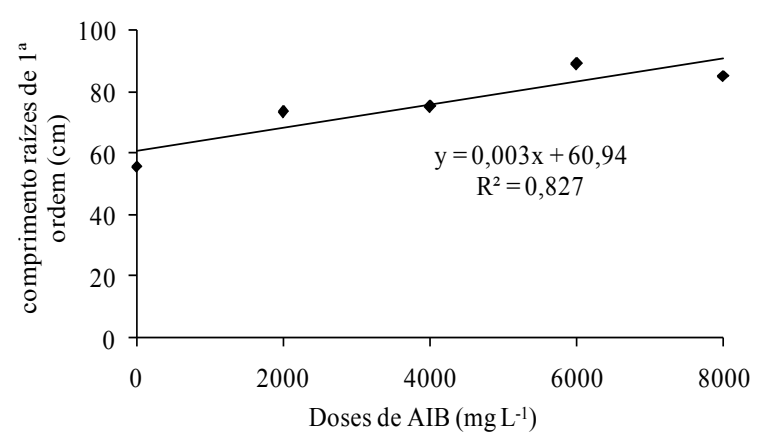

FIGURA 4: Comprimento de raízes de primeira ordem $(\mathrm{cm})$ em mudas de Handroanthus heptaphyllus, aos quatro meses do estaqueamento, em função das doses de ácido indol-3butírico. CV (\%): 18,0.

FIGURE 4: Length of $1^{\text {st }}$ order roots $(\mathrm{cm})$ in seedlings of Handroanthus heptaphyllus four months after staking, depending on the doses of indole-3butyric acid. CV (\%): 18,0.

$1000 \mathrm{mg} \mathrm{L}^{-1}$. Para Psidium cattleyanum, Nachtigal e Fachinello (1995) observaram que o tratamento da base das estacas com $4000 \mathrm{mg} \mathrm{L}^{-1}$ de AIB, proporcionou maior comprimento das raízes e 
com a aplicação de $6000 \mathrm{mg} \mathrm{L}^{-1}$, houve redução. Provavelmente, a maior concentração tenha causado efeito tóxico para as estacas.

\section{CONCLUSÕES}

Nas condições em que foi desenvolvido o experimento, conclui-se que, a utilização de AIB em miniestacas de ipê-roxo não é um condicionante para o enraizamento, embora tenha resultado em mudas com maior comprimento de raízes de primeira ordem e número de raízes de segunda ordem na concentração de $8000 \mathrm{mg} \mathrm{L}^{-1}$.

\section{AGRADECIMENTO}

Ao Conselho Nacional de Desenvolvimento Científico e Tecnológico (CNPq) pela concessão da bolsa de mestrado.

\section{REFERÊNCIAS BIBLIOGRÁFICAS}

ALCANTARA, G. B. de. et al. Efeitos do ácido indolilbutírico (AIB) e da coleta de brotações em diferentes estações do ano no enraizamento de miniestacas de Pinus taeda L. Scientia Forestalis, Piracicaba, v. 36, n. 78, p. 151-156, 2008.

ALMEIDA, F. D. et al. Eficiência das auxinas (AIB e ANA) no enraizamento de miniestacas de clones de Eucalyptus cloeziana F. Muell. Revista Árvore, Viçosa, v. 31, n. 3, p. 455-463. 2007.

ANDERSEN, L., BENTSEN, N. S. Survival and growth of Abies nordmanniana in forest and field in relation to stock type and root pruning prior to transplanting. Annals of Forest Science, Versailles, v. 60, n. 8, p. $757-762,2003$.

BEY, E. A. et al. An NQO1- and PARP-1-mediated cell death pathway induced in non-small-cell lung cancer cells by $\beta$-lapachone. Proceedings of the National Academy of Science, USA, v. 104, n. 28, p. 11832-11837, 2007.

BRASIL. Conselho Nacional do Meio Ambiente CONAMA. Resolução $n^{\circ}$. 307, de 05 de julho de 2002. Brasília. Diário Oficial da União, de 30 de Agosto de 2002, seção I, p. 17.241.

BRONDANI, G. E. et al. Ácido indolbutírico em gel para o enraizamento de miniestacas de Eucalyptus benthamii Maiden e Cambage x Eucalyptus dunnii Maiden. Scientia Agraria, Curitiba, v.9, n.2, p.153158, 2008.

CARVALHO, P. E. R. Espécies florestais brasileiras. v. 1, Colombo: EMBRAPA/CNPF. 2003a. 1039 p.
CARVALHO, P. E. R. Espécies Florestais Brasileiras: recomendações silviculturais, potencialidades e uso da madeira. Colombo: Embrapa. 1994. 640 p.

DIAS, P. C. et al. Propagação vegetativa de progênies de meios-irmãos de angico-vermelho (Anadenanthera macrocarpa (Benth) Brenan) por miniestaquia. Revista Árvore, Viçosa, v. 36, n. 3, p.389-399, 2012.

FACHINELLO, J. C. et al. Propagação de plantas frutíferas de clima temperado. 2. ed., Pelotas: Editora e Gráfica da UFPEL. 1995.168p.

FERREIRA, B. G. A. et al. Miniestaquia de Sapium glandulatum (Vell.) Pax com o uso de ácido indolbutírico e ácido naftaleno acético. Ciência Florestal, Santa Maria, v. 20, n. 1, p. 19-31. 2010.

FREITAS, T. A. S. et al. Manejo de miniestacas de eucalipto no setor de enraizamento para a produção em sistema de blocos. Scientia Forestalis, Piracicaba, v. 37. n. 84. p. 483-490. 2009.

GATTI, K. C. Propagação vegetativa de pau mulato (Calycophyllum spruceanum (Benth) K. Schum.), Jequitibá (Cariniana estrellensis (Raddi) Kuntze) e teca (Tectona grandis Linn. F.) por miniestaquia. 2002. $72 \mathrm{f}$. Tese (Doutorado em Ciência Florestal) - Universidade Federal de Viçosa, Viçosa.

GATTI, K. C. et al. Propagação vegetativa de Jequitibá (Cariniana estrellensis (Raddi) por miniestaquia. Temas Agrarios, Córdoba, v. 16, n. 2, p. 54-63, 2011.

HARTMANN, H. T. et al. Plant propagation: principles and practices. 7th Editon, New Jersey: Prentice-Hall. 2002. 880 p.

KOYAMA, J. et al. Cyclopentene dialdehydes from Tabebuia impetiginosa. Phytochemistry, v. 53, n. 8 p. 869-72, 2000.

LANA, R. M. Q. et al. Doses do ácido indolbutírico no enraizamento e crescimento de estacas de eucalipto (Eucalyptus urophylla). Bioscience Journal, Uberlância, v. 24, n. 3, p. 13-18, 2008.

LATTUADA, D. S. Micropropagação e miniestaquia de pitangueira (Eugenia uniflora L.). 2010. 75 f. Dissertação (Mestrado em Fitotecnia) - Universidade Federal do Rio Grande do Sul, Porto Alegre.

LORENZI, H. Árvores brasileiras: manual de identificação e cultivo de plantas arbóreas do Brasil. (2 ${ }^{\mathrm{a}}$ ed.). Instituto Plantarum, Nova Odessa, v. 2, 384p, 2002.

MAEDA, J. A.; MATTHES, L. A. F. Conservação de sementes de ipê. Bracatinga, Campinas, v. 43, n. 1, 
p.51-61. 1984.

NACHTIGAL, J. C.; FACHINELLO, J. C. Efeito de substratos e do ácido indolbutírico no enraizamento de estacas de araçazeiro (Psidium cattleyanum Sabine). Revista Brasileira de Agrociência, Pelotas, v. 1, p. 34-39. 1995.

NETO, G. G.; MORAIS, R. G. Recursos medicinais de espécies do cerrado de Mato Grosso: um estudo bibliográfico. Acta Botânica Brasileira, Belo Horizonte, v. 17, n. 4, p. 561-584, 2003.

OLIVEIRA, Y. et al. Substratos, concentrações de ácido indolbutírico e tipos de miniestacas no enraizamento de melaleuca (Melaleuca alternifólia Cheel). Revista Brasileira de Plantas Medicinais, Paulínia, v.14, n. 4, p. 611-616, 2012.

PACHECO, J. P. Estaquia de Luehea divaricata Mart. (açoita - cavalo). Dissertação (Mestrado em Engenharia Florestal) - Santa MariaRS, Universidade Federal de Santa Maria, 84p. 2007.

PARK, B. S. et al. Antibacterial activity of Tabebuia impetiginosa Martius ex DC (Taheebo) against Helicobacter pylori. Journal of Ethnopharmacology, v. 105, n. 1-2, p. 255-262, 2006.

PAULA, J. E.; ALVES, J. L. H. 897 Madeiras nativas do Brasil: anatomia, dendrologia, dendrometria, produção e uso. 1. ed. Porto Alegre: Cinco Continentes, 438p. 2007.

POTT, A.; POTT, V. J. Plantas do Pantanal.
Corumbá: Editora Embrapa/CPAP. 320 p. (1994).

SAMPAIO, P. T. B. et al. Propagação vegetativa por miniestaquia de preciosa (Aniba canellila (H. B. K) Mez). Acta Amazonica, Manaus, v. 40, n. 4, p. 687-692. 2010.

SANTOS, G. A. Propagação vegetativa de mogno, cedro rosa, jequitibá rosa e angico vermelho por miniestaquia. 2002. 75p. Monografia (Graduação) - Universidade Federal de Viçosa, Viçosa.

SOUZA, J. C. A. V. de. et al. Propagação vegetativa de cedro-australiano (Toona ciliata M. Roemer) por miniestaquia. Revista Árvore, Viçosa, v. 33, n. 2, p. 205-213. 2009.

TAIZ, L.; ZEIGER, E. Fisiologia vegetal. Porto Alegre: Artmed. 2004.

TITON, M. Propagação clonal de Eucalyptus grandis por miniestaquia e microestaquia. 2001. 65p. Dissertação (Mestrado em Ciência Florestal) Universidade Federal de Viçosa, Viçosa.

TITON,M.etal.Eficiênciadasminicepasemicrocepas na produção de propágulos de clones de Eucalyptus grandis. Revista Árvore, Viçosa, v. 27, n.5, p. 619-625. 2003.

ZANNI FILHO, J. Fundamentos para a estruturação de um viveiro. In. Produção de mudas em espécies florestais exóticas e nativas. Piracicaba: IPEF, p.12. 1997.

ZIMMERMANN, F. J. P. Estatística aplicada à pesquisa agrícola, Santo Ângelo de Goiás: EMBRAPA Arroz e Feijão. 400 p. 2004. 